\title{
IMPACT OF PHYSICAL MUTAGENS ON THE MALE GAMETOPHYTE OF THE TEA PLANT FOR ITS FURTHER USE IN HYBRIDIZATION \\ Davit Baratashvili ${ }^{1}$, Nino Lomtatidze ${ }^{2}$, Guguli Dumbadze ${ }^{3}$, Neli Khalvashi ${ }^{4}$, Nino Kedelidze ${ }^{5}$
}

\begin{abstract}
The migration of the radioisotopes - $\mathrm{P}^{32}$ and $\mathrm{S}^{35}$ from the soil to the tea plant (flowers) was studied. It is shown that their accumulation intensity in pollen sacs increases in proportion to the dose and reaches its maximum in the $\mathrm{P}^{32}$ variant after using a $8.0 \mathrm{MBq} / \mathrm{ml}$ dose. The migration intensity was the lowest in the $2.0 \mathrm{MBq} / \mathrm{ml}$ variant $(0.14-0.223 \mathrm{MBq} / 100 \mathrm{mg})$. It is estimated that $\mathrm{P}^{32}$ and $\mathrm{S}^{35}$ have significantly affected the vitality of tea plant pollens through the anomalies of their development. After using 2.0 and 4.0 MBq / ml doses, the vitality of the pollen is reduced in proportion to the dose and the development anomalies increase. Particulalry, the viability of pollen decrease compared to the control group, but the frequency and range of development anomalies increases. These include the slow development of the plant or the acceleration of the development of the primary nucleus, polyspermia, undeveloped pollen tube, etc. The use of processed $\mathrm{P}^{32}$ and $S^{35}$ tea pollens in hybridization significantly increases the frequency of new formations and results in variability in the domination of signs. Among the new formations include the induction of haploids and triploids.
\end{abstract}

UDC Classification: 575, DOI: 10.12955/cbup.v7.1469

Keywords: radioisotope, hybridization, domination, anomaly, gametophyte

\section{Introduction}

Apart from the impact on plant vegetative organs by radioisotopes $\left(\mathrm{P}^{32}, \mathrm{~S}^{35}\right)$, mutative selection widely uses the impact on plant pollen as well. This stage of ontogenesis is rather sensitive against the mutagenic factors of the environment. Therefore, there is a high probability occurring the various types of mutations (Avtandilashvili et al., 2004; Hirano et al., 2015).

The use of pollens treated with mutagens in hybridization makes favorable conditions for obtaining gametal or generative mutations, triploids, aneuploidies, androgenic haploids, and many other types of mutations. According to the above mentioned, the treatment of tea plant pollen with various mutagens for their further use in hybridization, for the sensitivity of the plant to mutagens at this stage of the ontogenesis, to enhance or weaken the dominance of individual signs in hybrid generations, and for other purposes is a really urgent issue for us (Stoilov, 2013).

The main purpose of the impact of mutagens on the masculine gametophyte of the tea plant was the study of their sensitivity to $\beta$ irradiation, anomalies in their development of pollen and its usage in hybridization, studying the peculiarities of dominance in the F1, and also receiving the perspective agricultural radiomutants. The pollen treated with mutagens, as a powerful factor, can also be used for breaking the tractions between genes, overcoming non-interbreeding and the formation of new forms of tea

\section{Data and methodology}

Based on the abovementioned, twice-substituted sodium phosphate - $\mathrm{Na}_{2} \mathrm{HPO}_{4}$, marked with phosphate $\left(\mathrm{P}^{32}\right)$, and sulfur barium - BaS, marked with sulfur $\left(\mathrm{S}^{35}\right)$ were used as mutagenic factors. The impact was made with a method developed by us. Specifically, during the boutonization period under 10-year-old tea bushes on a specially selected and wire fenced area, we used a solution of radioisotopes made from 3 liters of distilled water (radioisotopes activity was 2.0; 4.0 and $8.0 \mathrm{MBq} /$ $\mathrm{ml}$ ). Two varieties of tea plants (Tea sinensis L.) were used as a study object: Kolkheti and Kimin.

\footnotetext{
${ }^{1}$ Batumi Shota Rustaveli State University, Faculty of Natural Sciences and Health Care,Department of Biology, Adjara, Georgia, baratashvili.daviti@bsu.edu.ge

${ }^{2}$ Batumi Shota Rustaveli State University, Faculty of Natural Sciences and Health Care,Department of Biology, Adjara, Georgia, lomtatidze.nino@bsu.edu.ge

${ }^{3}$ Batumi Shota Rustaveli State University, Faculty of Natural Sciences and Health Care,Department of Biology, Adjara, Georgia, gugulidumbadze2@gmail.com

${ }^{4}$ Batumi Shota Rustaveli State University, Institute of Phytopathology and Biodiversiry, Department of

Biodiversity Monitoring and Conservation, Adjara, Georgia, n.khalvashi@bsu.edu.ge

${ }^{5}$ Batumi Shota Rustaveli State University, Adjara, Georgia, Faculty of Natural Sciences and Health

Care,Department of Biology; Institute of Phytopathology and Biodiversiry, Department of Biodiversity

Monitoring and Conservation, Adjara, Georgia, ninoqedelidze@bsu.edu.ge
} 
The migration of $\mathrm{P}^{32}$ and $\mathrm{S}^{35}$ in boutons was studied by the Geiger-Müller Beta calculator (GEIGER MULLER) by defining radioactivity in the pollen sacs. We were sowing pollen on the artificial nutrition area (15\% sucrose and $1 \mathrm{~g}$ agar-agar) and placing it on at room temperature. After 48 hours we fixed the material according to Karnua (6 part sof 96\% alcohol: 3 parts of chlorophyll: 1 parts of icy acetic acid) The fertility and development anomalies were studied in permanent preparations colored with hematoxylene (Geraskin and Sarapultseva, 2010). 5000 pollen grains were analysed in each variant

\section{Results and Discussion}

The data provided in Table 1 shows the migration of radioisotopes from the soil to the plant and in particular, is quite intense in the flower. The intensity of their accumulation in pollen sacs increases in proportion to the dose and reaches a maximum after the isotope replacement in the $\mathrm{P}^{32}$ variant after using an $8 \mathrm{MBq} / \mathrm{ml}$ dose $(3.2 \mathrm{MBq} 100 \mathrm{mg}$ on pollen sacs). The migration intensity was the lowest in the $2.0 \mathrm{MBq} / \mathrm{ml}$ variant of radio sulfur (0.14-0.223 MBq / $100 \mathrm{mg})$.

\begin{tabular}{|c|c|c|c|c|}
\hline \multirow[t]{3}{*}{$\begin{array}{l}\text { The specific activity of the } \\
\text { radioisotope } \mathrm{MBq} / \mathrm{ml}\end{array}$} & \multicolumn{4}{|c|}{$\begin{array}{l}\text { The intensity of accumulation of radionuclides calculated on } 100 \mathrm{mg} \\
\text { pollen sacs (MBq / } 100 \mathrm{mg} \text { ) }\end{array}$} \\
\hline & $P^{32}$ & $S^{35}$ & $P^{32}$ & $S^{35}$ \\
\hline & \multicolumn{2}{|c|}{ Kolkheti } & \multicolumn{2}{|c|}{ Kimini } \\
\hline 2.0 & $0.54 \pm 0.02$ & $0.23 \pm 0.02$ & $0.27 \pm 0.03$ & $0.14 \pm 0.03$ \\
\hline 4.0 & $1.0 \pm 0.05$ & $0.65 \pm 0.06$ & $0.60 \pm 0.03$ & $0.46 \pm 0.02$ \\
\hline 8.0 & $3.2 \pm 0.05$ & $1.20 \pm 0.17$ & $1.5 \pm 0.05$ & $1.15 \pm 0.01$ \\
\hline
\end{tabular}

Source: Author

Comparative analysis of the absorption intensity of radioisotopes in the tea varieties shows the obvious advantage of the tea variety of Kolkheti compared to Kimin. The abovementioned circumstance is due to the active growth of this variety, with the high capacity of sprouting and the velocity of various life processes, which in itself cause the intensive change of radioisotopes.

\begin{tabular}{|c|c|c|c|c|c|}
\hline \multirow[t]{2}{*}{$\begin{array}{l}\text { Name of } \\
\text { Radioisotope }\end{array}$} & \multirow{2}{*}{$\begin{array}{c}\text { Radioisotope } \\
\text { specific activity } \\
\text { MBq/ml }\end{array}$} & \multirow{2}{*}{$\begin{array}{c}\text { The vitality of } \\
\text { pollen sac, } \\
\%\end{array}$} & \multicolumn{3}{|c|}{$\begin{array}{c}\text { Anomalies of male gametophytes } \\
\text { development, \% }\end{array}$} \\
\hline & & & Pollen pipes & Pollen sacs & $\begin{array}{c}\text { Primary } \\
\text { core }\end{array}$ \\
\hline \multicolumn{6}{|c|}{ Kolkheti } \\
\hline \multirow[t]{3}{*}{$\mathbf{P}^{32}$} & 2.0 & $66.7 \pm 0.7 * * * *$ & $0.10 \pm 0.04$ & $10.80 \pm 040$ & $4.39 \pm 0.30$ \\
\hline & 4.0 & $67.9 \pm 0.7 * * *$ & $0.05 \pm 0.03$ & $13.43 \pm 0.50$ & $2.14 \pm 0.20$ \\
\hline & 8.0 & $4.8 \pm 0.3 * * *$ & $0.0 \pm 0.0$ & $52.2 \pm 0.70$ & $9.6 \pm 0.40$ \\
\hline \multirow[t]{3}{*}{$\mathbf{S}^{35}$} & 2.0 & $62.6 \pm 0.7 * * *$ & $0.02 \pm 0.14$ & $7.23 \pm 0.40$ & $4.58 \pm 0.30$ \\
\hline & 4.0 & $73.5 \pm 0.6^{* * * *}$ & $0.03 \pm \pm 0.14$ & $5.61 \pm 0.30$ & $3.03 \pm 0.30$ \\
\hline & 8.0 & $9.6 \pm 0.4 * * *$ & 0.00 .0 & $36.6 \pm 0.70$ & $6.7 \pm 0.40$ \\
\hline Control & & $82.0 \pm 0.5$ & $0.012 \pm 0.04$ & $8.13 \pm 0.40$ & $0.12 \pm 0.05$ \\
\hline \multicolumn{6}{|c|}{ Kimin } \\
\hline \multirow[t]{3}{*}{$\mathbf{P}^{32}$} & 2.0 & $75.3 \pm 0.6^{* * * *}$ & $0.93 \pm 0.14$ & $14.30 \pm 0.50$ & $3.46 \pm 0.30$ \\
\hline & 4.0 & $70.2 \pm 0.6^{* * * * *}$ & $0.08 \pm 0.04$ & $12.40 \pm 0.05$ & $1.13 \pm 0.40$ \\
\hline & 8.0 & $8.5 \pm 0.6 * * *$ & $0.0 \pm 0.0$ & $46.0 \pm 0.70$ & $8.20 \pm 0.40$ \\
\hline \multirow[t]{3}{*}{$S^{35}$} & 2.0 & $80.5 \pm 0.6^{* * * *}$ & $0.04 \pm 0.03$ & $13.3 \pm 0.50$ & $6.3 \pm 0.30$ \\
\hline & 4.0 & $77.0 \pm 0.6^{* * * *}$ & $0.01 \pm 0.01$ & $10.2 \pm 0.40$ & $2.69 \pm 0.20$ \\
\hline & 8.0 & $12.6 \pm 0.5^{* * * *}$ & $7.6 \pm 0.12$ & $26.21 \pm 0.50$ & $5.13 \pm 0.30$ \\
\hline Control & & $91.2 \pm 0.4$ & $0.01 \pm 0.01$ & $11.91 \pm 0.50$ & $0.19 \pm 0.06$ \\
\hline
\end{tabular}

In Table 2 which looks at the anomalies of development, the results of the study show that $\mathrm{P}^{32}$ and $\mathrm{S}^{35}$ significantly affect the vitality of the pollen sac in tea plant formation. For example, in the case of using 2.0 and $4.0 \mathrm{MBq} / \mathrm{ml}$ doses of the mutagen, the density of pollen sacs decreased by $10-20 \%$ and 
in the case of a $8.0 \mathrm{MB} / \mathrm{ml}$ dose, the density of pollen sacs decreased by 8-10 times $(4.8 \pm 0.3-12.6$ $\pm 0.5 \%$, versus $82.0 \pm 0.5-91.2 \pm 0.4 \%$ in the control), there are also cases when the pipes of the pollen sacs have cracked.

Note: In the tables 2 and 3, “*” are used for the represent $\mathrm{P}$ value determination when the data was compared with the control group. If a P-value is less than 0.05 , it is denoted with one star $(*)$. If a pvalue is less than 0.01 - with two stars $(* *)$, and a P-value less than 0.001 - with three stars $(* * *)$.

The cytogenetic analysis of the pollen sacs sown in the artificial nutrition area (15\% sucrose and 1gram agar-agar) indicates the occurrence of development anomalies with a high frequency when 8.0 $\mathrm{MBq} / \mathrm{ml}$ doses in both isotopes are used (36.6 versus 52.2\% instead of 8, 13 and $11.9 \%$ in control). In the identification of anomalies, violations were discovered such as the branching of pollen pipes (Polysyphonic type of branching), the formation of additional microsperms, the non-development of sperms, the disruption of the primary core, etc. A similar case of branching of the pollen pipe is observed in many types of angiospermous plants.

According to the data from Poddubnaya-Arnold (1976), on the mature pollen of Pisum Sativum and Allium cepa, by the low dose of X-rays, the normal process of division of the general cores are broken, and the additional microsperms are formed resulting in the different sizes of 3 to 5 sperm cores.

We have also described other anomalies of the general cores that are expressed in their uneven forms and degeneration and in an inability to produce sperms. The latter often becomes the cause of haploid generation.

Similar results were obtained by other researchers after the $\beta$-irradiation of pollens (Zhang et al., 2014).

The results of the hybrid analysis of the tea pollen treated with radionuclide are given in Table 3 . As shown in Table 3, the effect of $\mathrm{P}^{32}$ and $\mathrm{S}^{35}$ on the pollen with a $2 \mathrm{MBq} / \mathrm{ml}$ dose causes the stimulation of the useful knot of the fruit.

\begin{tabular}{|c|c|c|c|c|c|c|}
\hline \multirow{2}{*}{$\begin{array}{l}\text { Radio- } \\
\text { isotope- } \\
\text { specific } \\
\text { activity }\end{array}$} & \multirow{2}{*}{$\begin{array}{l}\text { Breeding } \\
\text { combination }\end{array}$} & \multirow{2}{*}{$\begin{array}{c}\text { Knotting, } \\
\%\end{array}$} & \multirow{2}{*}{$\begin{array}{c}\text { Seed } \\
\text { emergence, } \\
\%\end{array}$} & \multicolumn{3}{|c|}{ Native sign dominance, $\%$} \\
\hline & & & & $\begin{array}{c}\text { With } \\
\text { maternal } \\
\text { sign }\end{array}$ & $\begin{array}{c}\text { With } \\
\text { paternal } \\
\text { sign }\end{array}$ & $\begin{array}{c}\text { New } \\
\text { formation }\end{array}$ \\
\hline \multirow[t]{2}{*}{$\begin{array}{l}\mathbf{P}^{32} \\
(2 \mathrm{MBq} / \mathrm{ml})\end{array}$} & $\begin{array}{l}\text { Kolkheti X } \\
\text { Kimini }\end{array}$ & $\begin{array}{l}31.0 \pm \\
1.5^{*}\end{array}$ & $84.0 \pm 1.3$ & $19.3 \pm 1.7$ & $61.1 \pm 0.2$ & $4.4 \pm 1.1$ \\
\hline & $\begin{array}{l}\text { Kimini X } \\
\text { Kolkheti }\end{array}$ & $\begin{array}{l}29.3 \pm \\
1.4^{*}\end{array}$ & $86.0 \pm 1.2 *$ & $69.3 \pm 2.0$ & $16.5 \pm 1.4$ & $4.0 \pm 1.0 * *$ \\
\hline \multirow[t]{2}{*}{$\begin{array}{l}\mathrm{S}^{35} \\
(2 \mathrm{MBq} / \mathrm{ml})\end{array}$} & $\begin{array}{l}\text { Kolkheti X } \\
\text { Kimini } \\
\end{array}$ & $\begin{array}{l}32.0 \pm \\
1.58^{*}\end{array}$ & $79.9 \pm 1.4^{*}$ & $30.2 \pm 1.7 * *$ & $47.6 \pm 2.0 * *$ & $2.5 \pm 1.0 * *$ \\
\hline & $\begin{array}{l}\text { Kimini X } \\
\text { Kolkheti }\end{array}$ & $\begin{array}{l}29.8 \pm \\
1.4^{*} \\
\end{array}$ & $76.4 \pm 15$ & $51.1 \pm 2.0 * *$ & $32.8 \pm 2.0 * *$ & $3.9 \pm 1.1 * *$ \\
\hline \multirow[t]{2}{*}{ Control } & $\begin{array}{l}\text { Kolkheti X } \\
\text { Kimini }\end{array}$ & $23.9 \pm 1.3$ & $81.3 \pm 1.5$ & $19.8 \pm 1.5$ & $64.7 \pm 2.2$ & - \\
\hline & $\begin{array}{l}\text { Kimini X } \\
\text { Kolkheti }\end{array}$ & $21.1 \pm 1.3$ & $78.4 \pm 1.7$ & $69.8 \pm 2.3$ & $15.1 \pm 1.7$ & - \\
\hline
\end{tabular}

Genetic analysis of segregation in hybrid crops $\left(\mathrm{F}_{1}\right)$ was carried out at the end of the second year of the vegetation period. The results of the segregation analysis of the crops of the control variant indicate that dominance of the Kimini variety during the reciprocal breeding of Kimini and Kolkheti. The academician K. Bakhtadze also points to the abovementioned circumstance.

The results of our research show the weakening of the dominance of the Kimini variety and the relative strengthening of the Kolkheti variety, which, in our opinion is the result of the mutation of controlling genes or the suppression of their action. 
After using the irradiated pollen in hybridization, the change of the frequency of identification of variety is indicated in pear, apple, citrus, etc.(Spiegel -Roy and Padova, 1973).

Completely different forms, new formations (mutants) whose frequency was relatively high in the $\mathrm{P}^{32}$ variant were revealed in the hybrid descendants obtained from reciprocating tea breeding. As a result of analyzing the inclinations in the growth and development of new formations, some changes have rarely been revealed which are rarely observed in natural conditions in the tea plant including: haploidia, color change of leaf and crown sheets, as well as change of leave distribution (pryllotaxis), early fruit-harvesting (Neotenia) and others (Baratashvili, 2006).

Among the tea mutants, we have one haploid form $(n=15)$, which died 2 years after planting. The feature of early waking up of the buds of hybrid new formations is of particular interest. Such mutants are characterized by strong regeneration and sprouting ability.

Strengthening the formation processes after treating pollen mutations are associated with chromosome and gene mutations to a great extent.

\section{Conclusion}

The usage of P32 and S35 radioisotopes in tea plant selective-genetic researches and The scientific analysis of the obtained results allows us to make the following conclusions:

1. The migration of radioisotopes (P32 and S35) from the soil into the plant with an ongoing intensively. The intensity of their accumulation in the pollen parks rises proportionally to the dosage and reaches maximum after 24 hours, after entering the soil.

2. Comparative analysis of tea breeds in relation to the intensity of radioisotope absorption reveals the obvious advantage of the kolkheti tea breed in comparison to the Kimini breed. We have thought that the main reason for this is the high ability of sprout formation, which accompanied the intensive changing of radioisotopes.

3. The influence of radionuclides on the flower of the tea plant reliably reduces its viability (fertility) and significantly increases the development of anomalies.

4. The $\beta$-irradiation on the tea pollen grain revealed useful reliable stimulation of development of fruit, but $F_{1}$ hybrids - the variation of dominance. We have thought that this is the result of mutations in the single controlling genes or inhibition of their action.

5. The usage of treated pollen by radioisotopes in hybridization provide the stimulation of gamete mutations and increases the frequency of new forms.

\section{References}

Avtandilashvili, D., Baratashvili, D., Duncer, R., Mazmanidi, N., \& Pagava, S. (2004). Monitoring Radioecological situation in Marine and Coastal Environment of Georgia. (Radiation safety problems in the Caspian region, NATO Science series, iv. Earth and Environmetal Sciences, Khuwer Academic publishers, printed in the Netherlands, 41, 5.

Baratashvili, D., Alasania, N., \& Berulava, I. (2006). Cytogenetik Peculiarities of Mutation Variabilitu of Tea Plant in the Industrial Plantations of Ajara-Guria Region“. Bulletin of the Georgia Academy of Sciences, 173, 340.

Hirano T, Kazama Y, Ishii K, Ohbu S, Shirakawa Y, Abe T. Plant J. (2015) Comprehensive identification of mutations induced by heavy-ion beam irradiation in Arabidopsis thaliana. 2015 82(1):93-104. doi: 10.1111/tpj.12793.

Poddubnaya-Arnoldi, V.A. (1976). Cytoembryology of Angiospermae. Moscow: Nauka.

Spiegel-Roy, P.\& Padova, K. (1973). Radiosensitivity of chamonti orange (citrus sinensis) seeds end buds. Radiation Botany p. 91-103.

Stoilov, L. (2013). Karyotype reconstruction modulates the sensitivity of genome to radiation - induced DNA and chromosomal damage / L. Stoilov // Mutagenesis. Oxford University Press. 28, 153.

Geraskin, .SA. .\& Sarapultseva E.I. (2010). Biological control of the environment. Publishing Center Academy, 207 p.

Zhang, C., Yang, Y. P., \& Duan, Y. W. (2014). Pollen sensitivity to ultraviolet-B (UV-B) suggests floral structure evolution in alpine plants. Scientific reports, 4, 4520. doi:10.1038/srep04520. 